9. Федулова Т.П., Богачева Н.Н., Федорин Д.Н. Богомолов М.А., Ошевнев В.П. Молекулярно-генетическое изучение родительских форм и гибридов сахарной свеклы // Сахарная свёкла. - 2010. - № 8. - С. 8-10. - ISSN: 0036-3359.

10. Федулова Т.П., Богомолов М.А., Богачева Н.Н., Жужжалова Т.П., Федорин Д.Н., Ошевнев В.П., Хуссейн А.С. Подбор родительских пар для гибридизации с использованием ДНК-маркеров // Биотехнология: состояние и перспективы развития: материалы VI Московского международного конгресса. - М., 2011. - Ч. І. - С. 234-235. - ISBN: 5-7237-0372-2.

11. Davis B.J. Disc electrophoresis to human serum protein // Ann. N. - Y. Acad. Sci. -1964. - Vol. 121. - P. 404-427.

\title{
GENOTYPTIZATION OF WILD SPECIES AND SOME TABLE VARIETIES OF BEET (BETA L.) OF ARMENIA AS SELECTION INITIAL MATERIAL
}

\author{
Aloyan T. B., Badalyan M. V., Melikyan A. Sh. \\ Armenian National Agrarian University, \\ c. Yerevan,Armenia, e-mail: Tatev.Aloyan20@mail.ru
}

In recent years, plant breeding began to apply new methods based on the gene responsible for a certain feature of the plant. This point of view describing allelofonds and genotypes of beet cultivated varieties and their wild relatives has a important, scientific and practical significance. As the gene pool is a national treasure and its correct application has a great strategic importance, therefore, in order to clarify the genetic characteristics of species and use them as markers in the selection process, a task was set to study the polymorphism of proteins of some varieties and wild species of beet. Results of research allow to conclude that the locus of globulin all studied samples polymorphic and determine the indices of genetic similarity between them.

Key words: beet, electrophoresis, allelofond, genotype, globulin, genetic marker, selection material.

уДК 635.92:58.085

doi: 10.31360/2225-3068-2018-66-105-112

\section{ПРИМЕНЕНИЕ МЕТОДОВ БИОТЕХНОЛОГИИ В ДЕКОРАТИВНОМ РАСТЕНИЕВОДСТВЕ}

\author{
Галдина Т. Е., Калошин В. П., Самошин С. Е. \\ Федеральное государственное бюджетное \\ образовательное учреждение высшего образования \\ «Воронежский государственный лесотехнический университет им. Г. Ф. Морозова», \\ 2. Воронеж, Россия, e-mail: tatyana_galdina@mail.ru
}

В статье представлены результаты экспериментальной работы по применению метода микроклонирования для ряда сортов гортензий и роз. Объектом послужила гортензия крупнолистная ('Peppermint', 'Forever \& Ever Pink', 'Forever \& Ever Red', 'Forever \& Ever Blue', 'Phanton', 'Wim`s Red') 
и розы ('Pilgrim', 'Comtesse Du Barry’). Особое внимание сосредоточено на исследовании процесса перевода растений-регенерантов в естественные условия выращивания. Экспериментальным путём определены основные факторы, влияющие на эффективность процесса ризогенеза на этапе адаптации растений-регенерантов объектов исследования (биометрические показатели микрорастений на стадии перевода, агрохимических показателей субстратов).

Ключевые слова: микрорастения, in vitro, адаптация, сохранность, приживаемость, биометрические показатели, декоративные растения.

Применение методов биотехнологии для массового размножения декоративных растений имеет наибольшее значение для сельскохозяйственной практики с коммерческой точки зрения. К настоящему времени число видов, которые можно клонировать «в пробирке», уже составляет около тысячи. Однако широкого распространения эти методы в питомническом производстве не получили. Связано это с рядом причин, главной из которой является недостаточно разработанная законодательная база, регламентирующая производство, сертификацию и реализацию посадочного материала на территории Российской Федерации.

В настоящее время, одним из перспективных направлений использования биотехнологий является размножение широкого круга видов и форм декоративных растений, используемых для зелёного строительства.

В современных условиях неуклонно возрастающей антропогенной нагрузки на природную среду и резких изменений климата становится актуальной разработка новых подходов к решению проблем получения высококачественного, устойчивого, безвирусного посадочного материала для озеленения урбанизированных территорий.

В настоящее время, с развитием методов клонального микроразмножения, являющегося одним из способов вегетативного размножения, появился мощный инструмент для массового воспроизводства высококачественных декоративных растений. В качестве объектов этой in vitro-технологии могут быть использованы виды, сорта, гибриды, формы как имеющие затруднения при размножении традиционными методами, так и нуждающиеся в массовом тиражировании ввиду их высоких декоративных качеств [1-3, 5-7].

Однако получение высоких результатов при микроклональном размножении в значительной степени лимитируется одним из самых ответственных и трудоёмких этапов - адаптации растений-регенерантов к выращиванию ex vitro. До сих пор неудачи на этом этапе у многих 
Глава 4. Биотехнология растений

видов растений существенно снижают эффективность их размножения in vitro. В настоящий момент не существует универсальной технологии адаптации полученных растений-регенерантов, которая была бы пригодна для всех растений. Поэтому становится актуальной проблема совершенствовать приёмы адаптации растений-регенерантов, применение которых было бы одинаково успешно как для единичных ценных экземпляров растений, так и при их крупномасштабном тиражировании.

Объекты и методика исследования. Объектом исследования послужили следующие сорта декоративных растений: гортензии крупнолистной ('Peppermint', 'Forever \& Ever Pink', 'Forever \& Ever Red', 'Forever \& Ever Blue', 'Phanton', 'Wim`s Red') и розы ('Pilgrim', ‘Comtesse Du Barry’).

Материал для микроклонального размножения был предоставлен ООО «Селекционно-производственный центр Гагаринский».

Так как, целью микроразмножения является получение генетически однородных, идентичных материнскому растений, то традиционно используются технологии, основанные на активации уже существующих меристем. В качестве исходных эксплантов использовали сегмент побега (средняя часть) с пазушной почкой [1-3].

Далее экспланты помещали в пробирки на агаризованную питательную среду. В качестве базовой среды использовали среду Мурасиге и Скуга (MS), с добавлением (дополнением) цитокинина 6-БАП $(0,2$ и 1 мг/л) и гиббереллина ГА $(0,1$ мг/л). Для предотвращения выделения в культуральную среду фенольных соединений в среды добавляли поливинилпирролидон (3 г/л). Экспланты находились в культуральной комнате с температурой $27 \pm 1{ }^{\circ} \mathrm{C}, 16$-часовым фотопериодом и интенсивностью освещения 2 000-3 000 лк.

Все питательные среды содержали витамины и аминокислоты: глицин - 2 мг/л, никотиновая кислота и пиридоксин-НС1 - по 0,5 мг/л, тиамин - 1,0 мг/л, кроме того, аскорбиновая кислота - 2 мг/л, глутамин - 10 мг/л, мезоинозит - 100 мг/л. Гормоны предварительно растворяли в $1 \mathrm{H} \mathrm{NaOH}$ или 50\%-ном этиловом спирте и добавляли в соответствующих концентрациях к средам до автоклавирования. Среды были желированы добавлением 7,2 г/л агара. После растворения всех ингредиентов, $\mathrm{pH}$ среды был доведён до 5,6-5,8 с помощью $1 \mathrm{~N} \mathrm{NaOH}$. Автоклавирование сред, посуды и воды проводили с предварительной продувкой горячим паром (10 мин) в течение 20 мин при $121^{\circ} \mathrm{C}$.

Перевод пробирочных растений в открытый грунт осуществляли двумя способами:

- постепенная адаптация растений к нестерильным условиям;

- минуя этап адаптации в контейнерах со стерильным субстратом. 
Постепенную адаптацию растений-регенерантов проводили на установке для доращивания стеллажного типа при $\mathrm{t}=25^{\circ} \mathrm{C}$, освещённости 3 кЛк и 16-часовом фотопериоде. В качестве субстрата использовали смесь из песка и дерновой земли $(1: 3)$.

Для второго способа в марте растения-регенеранты, размноженные in vitro, пересаживали в ёмкости со стерильным субстратом для укоренения. Ёмкости располагали в тепличных условиях $\left(\mathrm{t}+21^{\circ} \mathrm{C}\right.$, при освещённости 5 кЛк и 12-часовом фотопериоде). В мае высаживали в открытый грунт.

Стерильный субстрат представлен был 6 вариантами почвогрунтов:

1) торф : песок (1:3);

2) торф : песок : перегной $(1: 1: 1)$;

$3)$ торф : песок : перегной : вермикулит (1:1:1:1);

4) торф : песок : перегной : вермикулит $(2: 1: 1: 1)$;

5) торф : песок : перегной : вермикулит (1:2:1:1);

6) торф : песок : перегной : вермикулит $(1: 1: 2: 1)$.

На этапе адаптации к почвенным условиям молодые растения регулярно поливались.

Приживаемость растений фиксировали при появлении новых листьев. Оценка основных параметров роста растений в зависимости от применяемых субстратов проводилась путём измерения линейных размеров.

Результаты и их обсуждения. В ходе работы начало развития почек наблюдали на 5-7 день культивирования эксплантов.

На этапе формирования розетки листьев растения пересаживали на среду $1 / 2$ MS (половинного по макросолям состава) с двойным содержанием сахарозы и хелата железа, а также с добавлением 6-БАП в концентрации 0,1 мг/л, что позволило через 45 дней после хорошо сформированной розетки перейти к этапу мультипликации (черенкования).

Перевод растений-регенерантов из стерильных условий в грунт осуществляли постепенно, в несколько этапов.

В таблице 1 представлены результаты влияния биометрических показателей растений-регенерантов на приживаемость при переводе (постепенной через установку для доращивания) в нестерильные условия (ex vitro).

На основе биометрических измерений при посадке и учёте приживаемости растений через 45 дней после высадки микрорастений из сосудов в субстрат выявлено, что растения с размерами более 3,0 см (для всех видов гортензий) и более 5,0 см (для роз) и с развитой корневой системой хорошо адаптируются в почвенном субстрате (табл. 1). 


\section{Таблий 1}

Приживаемость растений-регенерантов в зависимости от биометрическихпоказателей при пересадке в грунт, 45 дней

\begin{tabular}{|c|c|c|c|c|c|c|}
\hline & Наименование & $\begin{array}{c}\text { Высота } \\
\text { розетки, } \\
c м\end{array}$ & $\begin{array}{l}\text { Количество } \\
\text { корней, } \\
\text { шт./pacme- } \\
\text { ние }\end{array}$ & $\begin{array}{c}\text { Средняя } \\
\text { длина } \\
\text { корней, } \\
\text { см }\end{array}$ & $\begin{array}{c}\text { Корни } \\
\text { второго } \\
\text { порядка, } \\
+/-\end{array}$ & $\begin{array}{c}\text { Прижи- } \\
\text { ваемость } \\
\text { растений, } \\
\%\end{array}$ \\
\hline \multirow{2}{*}{1} & \multirow{2}{*}{\begin{tabular}{|l|}
$\begin{array}{l}\text { Гортензия } \\
\text { 'Peppermint' }\end{array}$ \\
\end{tabular}} & $3,8 \pm 0,17 *$ & $2,4 \pm 0,14$ & $1,8 \pm 0,12$ & - & 18,4 \\
\hline & & $4,6 \pm 0,12 * *$ & $5,6 \pm 0,12$ & $3,9 \pm 0,14$ & + & 56,6 \\
\hline \multirow{2}{*}{2} & \multirow{2}{*}{$\begin{array}{l}\text { Гортензия } \\
\text { 'Forever \& Ever Pink' }\end{array}$} & $3,2 \pm 0,21$ & $3,2 \pm 0,34$ & $3,2 \pm 0,34$ & - & 21,3 \\
\hline & & $5,8 \pm 0,35$ & $7,1 \pm 0.12$ & $4,8 \pm 0,27$ & + & 86,6 \\
\hline \multirow{2}{*}{3} & \multirow{2}{*}{$\begin{array}{l}\text { Гортензия } \\
\text { 'Forever \& Ever Red' }\end{array}$} & $2,9 \pm 0,24$ & $2,8 \pm 0,33$ & $3,6 \pm 0,12$ & - & 27,1 \\
\hline & & $5,3 \pm 0,37$ & $7,6 \pm 0,12$ & $4,2 \pm 0,17$ & + & 88,1 \\
\hline \multirow{2}{*}{4} & \multirow{2}{*}{$\begin{array}{l}\text { Гортензия } \\
\text { 'Forever \& Ever Blue' }\end{array}$} & $1,2 \pm 0,33$ & $3,2 \pm 0,25$ & $1,1 \pm 0,23$ & - & 5,2 \\
\hline & & $5,2 \pm 0,27$ & $4,6 \pm 0,12$ & $3,8 \pm 0,33$ & + & 62,5 \\
\hline \multirow{2}{*}{5} & \multirow{2}{*}{$\begin{array}{l}\text { Гортензия } \\
\text { 'Phanton' }\end{array}$} & $2,1 \pm 0,31$ & $3,7 \pm 0,14$ & $3,2 \pm 0,14$ & - & 21,1 \\
\hline & & $4,8 \pm 0,35$ & $6,6 \pm 0,15$ & $4,2 \pm 0,16$ & + & 74,6 \\
\hline \multirow{2}{*}{6} & \multirow{2}{*}{$\begin{array}{l}\text { Гортензия } \\
\text { ‘Wim`s Red' }\end{array}$} & $3,2 \pm 0,34$ & $2,2 \pm 0,37$ & $2,2 \pm 0,27$ & - & 15,6 \\
\hline & & $5,2 \pm 0,35$ & $5,6 \pm 0.12$ & $4,2 \pm 0,36$ & + & 74,5 \\
\hline \multirow{2}{*}{7} & \multirow{2}{*}{\begin{tabular}{|l} 
Poзa \\
'Pilgrim'
\end{tabular}} & $1,2 \pm 0,37$ & $1,5 \pm 0,14$ & $1,2 \pm 0,10$ & - & 11,3 \\
\hline & & $3,2 \pm 0,33$ & $3,6 \pm 0,24$ & $3,6 \pm 0,12$ & + & 66,2 \\
\hline \multirow{2}{*}{8} & \multirow{2}{*}{\begin{tabular}{|l} 
Poзa \\
'Comtesse Du Barry'
\end{tabular}} & $1,6 \pm 0,21$ & $1,2 \pm 0,21$ & $2,1 \pm 0,12$ & - & 5,1 \\
\hline & & $3,0 \pm 0,34$ & $3,1 \pm 0,17$ & $3,2 \pm 0,11$ & + & 52,8 \\
\hline
\end{tabular}

Примечание: * - растения без образования корней второго порядка; ** - растения, имеющие корни второго порядка

Наши результаты показали, что на приживаемость пробирочных растений в почвенном субстрате влияют биометрические показатели микрорастений: высота растения, количество и длина корней. Хорошо приживаются растения с сильно развитой корневой системой, которая представлена корнями I и II порядков.

При переводе регенерантов в почвенные условия во избежание массовой гибели растений применяют различные технологические элементы, которые улучшают качество субстратов. Обычно в качестве компонента, удерживающего влагу, используют слаборазложившийся торф из сфагнового мха, а для улучшения воздушного режима - крупнозернистый песчаник, не содержащий щелочных примесей. В настоящее время для улучшения агрофизических и физико-химических показателей субстратов используют природный материал - вермикулит. 
Как отмечает Л. А. Иванова (2008), торф и песок в той или иной степени улучшают свойства субстрата, но растения, выращенные на нём, как правило, плохо развиваются и зачастую не способны бороться с опасной микрофлорой [4]. В наших работах при использовании для адаптации почвогрунта из торфа и песка, также отмечалась низкая приживаемость растений и слабое развитие растений на протяжении всего периода исследований (табл. 2).

Таблица 2

Влияние агрохимических показателей субстратов на приживаемость растений-регенерантов

\begin{tabular}{|c|c|c|c|c|c|c|c|c|c|c|c|c|c|}
\hline \multirow[b]{2}{*}{ № } & \multirow[b]{2}{*}{$\begin{array}{c}\text { Тип } \\
\text { субстрата }\end{array}$} & \multicolumn{4}{|c|}{$\begin{array}{c}\text { Агрохимические } \\
\text { показатели субстратов }\end{array}$} & \multicolumn{8}{|c|}{$\begin{array}{c}\text { Приживаемость, } \\
\text { \% }\end{array}$} \\
\hline & & 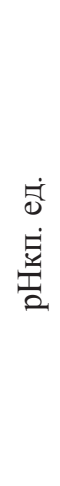 & 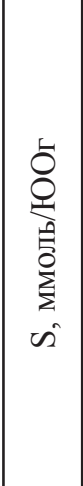 & 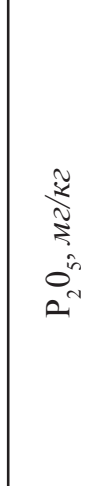 & $\frac{\sqrt{2}}{2}$ & 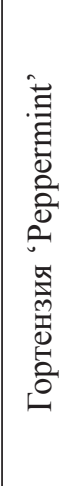 & 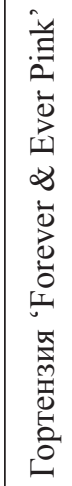 & 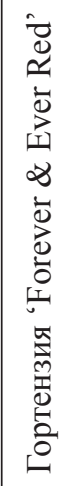 & 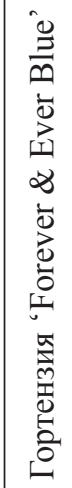 & 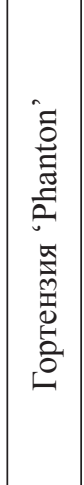 & 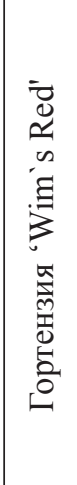 & 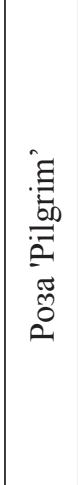 & 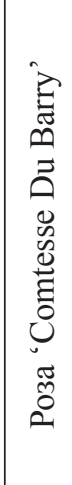 \\
\hline 1 & \begin{tabular}{|l|} 
Песок : дерновая \\
земля (1 : 3) (Уста- \\
новка для доращи- \\
вания стеллажного \\
типа) \\
\end{tabular} & 6,2 & 42,3 & 598,8 & 888,0 & 95,2 & 78,2 & 88,1 & 54,1 & 77,1 & 88,3 & 66,2 & 56,3 \\
\hline 2 & Торф : песок (1 : 3) & 5.8 & 38,1 & 98,5 & 65,0 & 47,8 & 56,3 & 57,1 & 31,3 & 58,9 & 47,3 & 4,3 & 5,3 \\
\hline 3 & $\begin{array}{l}\text { Торф : песок : пе- } \\
\text { регной }(1: 1: 1)\end{array}$ & 6,6 & 36,4 & 447,5 & 530.0 & 64,4 & 76,2 & 71,8 & 50,3 & 64,5 & 72,8 & 45,3 & 47,3 \\
\hline 4 & $\begin{array}{l}\text { Торф : песок : } \\
\text { перегной: верми- } \\
\text { кулит (1 : } 1: 1: 1)\end{array}$ & 6,8 & 41,5 & 431,1 & 437,5 & 54,4 & 71,3 & 78,9 & 49,5 & 56,3 & 72,3 & 39,2 & 37,3 \\
\hline 5 & $\begin{array}{l}\text { Торф : песок : } \\
\text { перегной : верми- } \\
\text { кулит }(2: 1: 1: 1)\end{array}$ & 6.8 & 42,5 & 371,1 & 340,0 & 36,2 & 61,3 & 68,6 & 52,3 & 60,3 & 61,8 & 23,1 & 31,8 \\
\hline 6 & $\begin{array}{l}\text { Торф : песок : } \\
\text { перегной : верми- } \\
\text { кулит }(1: 2: 1: 1)\end{array}$ & 6,4 & 44.5 & 397,0 & 467,5 & 41,4 & 62,3 & 75,8 & 57,8 & 61,3 & 86,3 & 37,9 & 33,9 \\
\hline 7 & $\begin{array}{l}\text { Торф : песок : } \\
\text { перегной : верми- } \\
\text { кулит }(1: 1: 2: 1)\end{array}$ & 6,8 & 44,5 & 671,1 & 878,0 & 88,0 & 92,1 & 95,3 & 66,3 & 73,2 & 93,2 & 50,3 & 51,1 \\
\hline
\end{tabular}


Глава 4. Биотехнология растений

Сравнительный анализ субстратов показал, что наиболее важным компонентом почвенной смеси для укоренения и дальнейшего роста растений является перегной. Высокая приживаемость растений отмечалась в субстратах, имеющих повышенное содержание перегноя (более 33,3 \% от общего объёма). Также отмечена высокая приживаемость растений в почвенной смеси с вермикулитом, который улучшает агрофизические свойства субстрата и характеризуется хорошей водоудерживающей способностью, что препятствует иссушению растений в процессе адаптации.

Сравнительный анализ позволил отметить прямую взаимосвязь содержания Р, К в почвогрунте с приживаемостью и ростом. Так отмечено, что высокое содержание фосфора и калия в почвогрунте благоприятно сказывается на повышении адаптационных способностей растений.

Длительность эксперимента по адаптации растений к почвенным условиям составила 3 месяца. При завершении этапа адаптации во всех вариантах отмечался активный рост и развитие растений, в результате которого растения сформировали хорошо развитые розетки.

Растения через 90 дней после высадки в грунт, независимо от типа субстрата, сформировали примерно одинаковую наземную часть. При этом они находились в виргинильном состоянии, которое характеризовалось отрастанием на укороченном осевом побеге боковых побегов (дочерних розеток) в основании с 1 или 2 парами листьев.

Выводы. В результате проведенной работы, были отмечены следующие закономерности: при высадке в почвенный субстрат растенийрегенерантов корневая система должна быть хорошо развита, а также хорошо развиты листья (розетки), обусловливающие их способность к фотосинтезу.

Для адаптации растений-регенерантов, минуя установки для доращивания, вполне приемлемы тепличные условия $\left(\mathrm{t}=+21{ }^{\circ} \mathrm{C}\right.$, освещённость 5 кЛк и 12-часовой фотопериод), что снижает затраты на дополнительное оборудование и т. п. В качестве почвогрунта рекомендуется применять следующий субстрат: торф : песок : перегной : вермикулит в соотношении $1: 1: 2: 1$. Использование вермикулита в составе почвогрунтов позволяет создать оптимальный водно-воздушный режим и режим минерального питания, тем самым получить благоприятные условия для адаптации растений, обеспечивая максимальную приживаемость и высокие темпы роста растений. 
Субтропическое и декоративное садоводство (66)

\title{
Библиографический список
}

1. Биотехнология растений: культура клеток / Пер. с англ. В.И. Негрука; с предисл. Р.Г. Бутенко. - М.: Агропромиздат, 1989. - 280 с.

2. Бутенко Р.Г. Биология высших растений in vitro и биотехнологии на их основе: учебное пособие. - М.: ФБК, Пресс, 1999. - 160 с.

3. Вечернина Н.А. Биотехнология растений: учебное пособие. - Барнаул: Изд-во Алт. ун-та, 2009. - 224 с. - ISBN: 978-5-7904-0899-1.

4. Иванова Л.А. Субстрат для культивирования растений-регенерантов при микроклональном размножении // Биотехнология как инструмент сохранения биоразнообразия растительного мира: материалы II Всероссийской научно-практической конференции г. Волгоград, 19-21 августа 2008 г. - Белгород: Изд-во БелГУ, 2008. - С. 171-174.

5. Катаева Н.В., Бутенко Р.Г. Клональное микроразмножение растений. - М.: Наука, 1983. - 96 с.

6. Лутова Л.А. Биотехнология высших растений: учебник. Изд. 2-е. - СПб.: Изд-во СПб. ун-та, 2010. - 240 с. - ISBN: 978-5-288-05048-0.

7. Поздняков И.А. Особенности микроклонального размножения шиповника и декоративных сортов рода Rosa L.: дис. ... канд. с.-х. наук. - М., 2007. - 220 с.

\section{APPLYING BIOTECHNOLOGY TECHNIQUES IN ORNAMENTAL HORTICULTURE}

\author{
Galdina T. Ye., Kaloshin V. P., Samoshin S. Ye.
}

Federal State Budgetary Educational Institution of Higher Education

"Voronezh State University of Forestry Engineering named after G. F. Morozov",

c.Voronezh, Russia, e-mail: tatyana_galdina@mail.ru

The paper presents the results of experimental work on microcloning technique for a number of hydrangea and rose cultivars. The object was large-leaved hydrangeas ('Peppermint', 'Forever \& Ever Pink', 'Forever \& Ever Red', 'Forever \& Ever Blue', 'Phanton', 'Wim's Red') and roses ('Pilgrim', 'Comtesse Du Barry'). Particular attention is focused on the study of placing regenerating plants into natural growing conditions. The main factors influencing rhizogenesis process efficiency at the adaptation stage are defined experimentally (biometric indicators of microplants at the stage of placing, agrochemical indicators of substrates).

Key words: microplants, in vitro, adaptation, preservation, survival ability, biometric indicators, ornamental plants. 